\title{
Camel milk-sweet potato starch gel: steady shear and dynamic rheological properties
}

\author{
Abdellatif A. MOHAMED ${ }^{1 \star}$ (D), Shahzad HUSSAIN ${ }^{1}$, Mohammed S. ALAMRI ${ }^{1}$, Mohamed A. IBRAHEEM ${ }^{1}$, \\ Akram A. Abdo QASEM ${ }^{1}$, Hany YEHIA ${ }^{1}$
}

\begin{abstract}
Camel milk is known to produce low quality gels. To address this drawback, sweet potato starch (SP), camel milk (CM), or cow milk (CWM) were blended and cooked in alkaline conditions. The rheological tests of the prepared gel were done using DHR- Hybrid Rheometer. Because the G' was, by far, larger than G”, the prepared gel exhibited viscoelastic behaviour as well as shear thinning. The gel exhibited $\tan \delta<1.0$ which indicates solid-like material, but obvious variances between the gels were detected. The gels prepared from CM were harder than CWM, but it was frequency-dependent at low frequencies from 0.1 to $1.0(\mathrm{rad} / \mathrm{sec})$. Samples containing camel milk presented stronger structure due to the low power law exponent ( $n$ ), while CWM showed more shear thinning. The obvious high G' and the low $(n)$ value is projected to have processing repercussions on $\mathrm{CM}$ gel.
\end{abstract}

Keywords: camel milk; rheology; gel; texture; dairy processing.

Practical Application: Improve camel milk gel properties.

\section{Introduction}

The population of Camels in the world is about 28 million while camel milk production is about 2.85 million tons (Food and Agriculture Organization, 2017). Despite its unique chemical composition, fermented camel produces weak gels (Kaskous, 2016; Khan \& Alzohairy, 2011). Fermented camel milk products are characterized as watery, weak, and poor structure (Rahman et al., 2009). Probably, this distinguishing property is because of the extended structure and limited dispersion of casein and the lack of Beta-lactoglobulin (b-lg) in camel milk compared with CWM milk (Al Haj \& Al Kanhal, 2010; El-Agamy et al., 2009; Kamal et al., 2017). The average molecular size of camel milk casein is $468 \pm 1.00 \mathrm{~nm}$, whereas CWM milk is $137 \pm 1.50 \mathrm{~nm}$. This difference explains the variation in the physicochemical properties between the CWM and camel milk (Bornaz et al., 2009; Kamal et al., 2017). The average camel milk composition is $2.2-6.1 \%$ fat, $3.2-5.6 \%$ lactose, $3.0-3.9$ protein, $0.6-1.0$ ash, and specific gravity of 1.026-1.036 (Getachew, 2003). Camel milk is rich in insulin, vitamins and minerals such as sodium, potassium, iron, copper, zinc and magnesium and low in cholesterol (Al-Hashem, 2009; Rao et al., 1970). Current findings indicate that the antidiabetic action of camel is not due to insulin action. Therefore, in an effort to determine the antidiabetic action of camel milk, researchers reported that insulin was not responsible for that this activity and suggested further research to determine the real cause (Abou-Soliman et al., 2020).

By virtue of its high vitamin C content $(58.5 \mathrm{mg} / \mathrm{kg})$ and low lactose content (for lactose intolerant consumers), it is possible to keep camel milk at ambient temperature for extended time (Singh et al., 2006). Therefore, camel milk is nutritious in addition to its medicinal value (Shabo et al., 2005; Shalash, 1980).
Camel milk has salty taste and opaque white color due to the small fat particles which consist mainly of long chain poly unsaturated fatty acid (Abu-Lehia, 1987). The average protein content of Camel milk is $2.65 \%$ but it lacks the allergic $\beta$-lacto globulin and different $\beta$-casein composition compared to other milks. Camel milk exhibits immunological and antioxidant activity, and contains various enzymes with antibacterial activity (Kappeler, 1998). A number of proteins known for their defensive and immunological action in camel milk are lysozymes, lactoferrin, lactoperoxidase, and peptydoglycon-recognition protein (Mal et al., 2006; Morin et al., 1995; Singh et al., 2006). Soft gel of camel milk can be attributed to the high ratio of whey protein to casein (Abu-Tarboush, 1996; Berhe et al., 2018; Shamsia, 2009).

Due to the soft gel of camel milk, researcher made efforts to improve the poor textural properties of camel milk products. Some of the approaches used were to fortify camel milk with powdered skim CWM milk (Salih \& Ahmed Hamid, 2013) or by adding hydrocolloids or stabilizers (Al-Zoreky \& Al-Otaibi, 2015). One of the most encouraging attempts to improve the gelling properties of camel milk was the use of microbial transglutaminase (MTGase) (Abdulqadr et al., 2014; Farnsworth et al., 2006; Ozer et al., 2007). Acceptable gel-firmness can be reached by incorporating $\mathrm{CaCl}_{2}$ or sodium phosphate signified by higher G' and lower gelation time (Kamal et al., 2017).

Casein proteins are characterized as extended molecule with long coil-like or as subunits that can be considered as supermolecule (Farrell et al., 2006). Conversely, in alkaline environment such as urea, it disentangles, which is evident of hydrogen bonding between the supermolecule unites (Holt, 
1998). Although it is high in $\beta$-casein (65\% versus $39 \%$ ), camel milk is low in a (22\% versus 38\%) and kappa casein $(3.5 \%$ versus 13\%) (Yagil, 1982). This is also reflected by the different amino acid distribution. The lower $\mathrm{k}-\mathrm{CN}$ content and the larger micelle size of camel milk result in the formation of a less firm gel and lower yield during cheese and yoghurt processing (Bornaz et al., 2009; Konuspayeva et al., 2014). Reports in the literature reveled major changes of proteins secondary structure or complete denaturation by urea especially at $8 \mathrm{M}$ solution, but protein molecules can open up at lower urea concentration due to the reduction in hydrogen bonding without reaching denaturation. Spray drying of camel and cow milk showed that camel exhibited significant higher loose bulk density than that of cow milk powder, whereas no statistical difference between the solubility of both types of milk powder. In addition, reports suggested that the differences between the two milk types can be ascribed to the physicochemical differences between camel and cow milk, especially the fat globule characteristics (Zouari et al., 2020). Because of the week gel of camel milk and the suggested approach to enrich camel milk with some type of hydrocolloids, it is important to develop ways by which to present the product to new consumers. Although dairy products are consumed by a vast majority of food consumers, new methods of advertising and presenting of new and existing products are needed. Diary method and Completion Task are the nuts and bolts tools of expanding dairy products to new consumers (Torres et al., 2020; Rodrigues et al., 2021)

The objective of this work was focused on determining the textural properties of precooked camel milk gel enriched with sweet potato starch in urea solution ( $\mathrm{pH}$ 7.5). Because, when starch is heated in the presence of appreciable amount of water, it gelatinizes and form a vicious gel. This will increase the likelihoods of physical entanglement between camel milk protein and the gelatinized starch (amylose or amylopectin) to form the final gel-network. This gel is expected be firmer and more coherent than camel milk gel alone due to the starch.

\section{Materials and methods}

\subsection{Milk samples}

Pasteurized camel and CWM milk was donated by King Saud University farm (Riyadh, Saudi Arabia). Milk was pasteurized at $85^{\circ} \mathrm{C}$ for $15 \mathrm{~min}$ then cooled to room temperature before freeze drying. Both milks were freeze-dried and stored at $-20^{\circ} \mathrm{C}$. Sweet potato starch was prepared using the methods of Alamri et al. (2016).

\subsection{Gel preparation}

Blends of freeze-dried camel (CM) or Cow milk (CWM) and sweet potato starch (SP) were prepared as follows; high milk blends at 90:10 or 70:30 milk:SP (high milk blends) i.e., $90 \mathrm{~g}$ of milk and $10 \mathrm{~g}$ of sweet potato starch. The second set was milk:SP 50:50. The third was high starch blends SP:milk at 90:10, 70:30 (this is high starch blends) i.e., $90 \mathrm{~g}$ sweet potato starch and $10 \mathrm{~g}$ milk. Gels were prepared by cooking a suspension of dry blends in 2.0 M aqueous urea solution ( $\mathrm{pH}$ 7.5) using Rapid Visco Analyzer (RVA). The prepared gel is then transferred to the dynamic rheometer for analysis. Slurry was prepared by mixing dry blends with urea solution, where $2.8 \mathrm{~g}$ ( $14 \%$ moisture content) and urea solution $(2.0 \mathrm{M})$ was added to reach $28 \mathrm{~g}$. The obtained slurry was loaded on RVA (Newport Scientific, Sydney, Australia). After $30 \mathrm{sec}$ at $50^{\circ} \mathrm{C}$, it was then heated to $95^{\circ} \mathrm{C}$ in $4.40 \mathrm{~min}$ and held for $4 \mathrm{~min}$. The temperature of the gel was brought to $50{ }^{\circ} \mathrm{C}$ in $2 \mathrm{~min}$ and kept for $2 \mathrm{~min}$. At the first $10 \mathrm{sec}$, the paddle rotated at $960 \mathrm{rpm}$ and reduced to $160 \mathrm{rpm}$ for the remaining time of the experiment.

\subsection{Dynamic rheological measurements}

The gel prepared using RVA was transferred to the rheometer for dynamic rheological testing. DHR-1 Hybrid Rheometer was used to determine the dynamic rheological testing (TA instruments, DE, USA). The rheometer is equipped with $40 \mathrm{~mm}$ diameter parallel plates with $50 \mu \mathrm{m}$ gaps and the temperature was set at $25^{\circ} \mathrm{C}$ or $40^{\circ} \mathrm{C}$ during the rheological testing. Before shear testing, a strain-sweep was done to establish the linear viscoelastic region of the precooked gels. Small amplitude oscillatory shear tests were conducted in the range of $0.1-100(\mathrm{rad} / \mathrm{sec})$ frequency at $5 \%$ shear strain. Shear storage modulus (G'), loss modulus (G") and complex viscosity ( $\eta^{\star}$ Pa.s) were the measured parameters. All calculations were made using the Rheology Advantage Data Analysis software (Version 5.7.0.) provided by the manufacturer of the rheometer.

To show that all data collection was in the range of the linear viscoelastic, a strain-sweep was performed. To establish that G, $G$ ", and $\eta^{*}$ were in the linear region, strain sweep was conducted to determine the linear viscoelastic region. The behavior of all measured materials in this study was in the linear range below $13 \%$ strain. Linear viscoelasticity proves that all measured parameters were shear strain independent. Testing was done at least in duplicates with fresh samples and the errors were at $\pm 10 \%$. The $\mathrm{G}^{\prime}$ is the non-dissipative component, while the loss modulus indicates the dissipative element of the mechanical properties. Elastic materials are characterized by $\mathrm{G}^{\prime}$ independent of frequency and greater than G", however G" represents the viscous texture. The phase angle $(\delta)$ of solid materials is zero while $\delta=90$ for the liquid with perfect viscosity. The $\tan ^{-1}\left(G^{\prime \prime} / G^{\prime}\right)$ is the definition of the phase angle.

\subsection{Steady shear measurements}

Nonlinear experiment was done using the same instrument (DHR- Hybrid Rheometer). The steady shear test was conducted at $0.1-100 \mathrm{~s}^{-1}$ shear rate while the data was collected every $20 \mathrm{sec}$. Measurements were done in duplicate with fresh samples for each run. The relative errors between the runs were within the range of $\pm 10 \%$.

\subsection{Gel texture}

Milk and SP blends were prepared at 10,30, and 50\% milk content. Blends were cooked using RVA and placed in $25 \mathrm{~mL}$ glass beakers ( $35 \mathrm{~mm}$ in height), stored at room temperature and tested after $12 \mathrm{hr}$. Gels texture measurement was accomplished by compressing the gels using Brookfield CT3 Texture Analyzer (Brookfield Engineering Laboratories, Inc. Middleboro, USA). 
Two cycles penetration were performed at $0.5 \mathrm{~mm} / \mathrm{s}$ to $10 \mathrm{~mm}$ into the gel using cylinder-shaped probe with $12.7 \mathrm{~mm}$ wide and $35 \mathrm{~mm}$ high.

\section{Results and discussion}

The data presented here was separated into two groups, high and low milk content. In dynamic rheological testing, storage modulus G', loss modulus G" and complex viscosity $\eta^{*}$ are the most measured parameters. The magnitude of changes to these parameters was quantified by creating perfect experimental conditions such as oscillation frequency, strain, temperature, and testing near the linear viscoelastic region (LVR) of the material. In this study, the LVR was represented by wide-ranging temperatures. Therefore, $5 \%$ strain at 25 to $50{ }^{\circ} \mathrm{C}$ was found to be within the LVR. Some researchers used up to $50 \%$ strain for the cooked starch-water systems between 10 and 47 ( $\mathrm{rad} / \mathrm{sec})$ frequencies (Abd Karim et al., 2000; González-Reyes et al., 2003; Lagarrigue \& Alvarez, 2001). Although the applied 5\% strain was sufficiently low to keep the experiment within the LVR, it allows for gel characterization without causing major structural changes (Tattiyakul \& Rao, 2000).

\subsection{G' and G" of sweet potato and milk blends}

\section{High starch content blends}

As suggested by other researchers, $G$ ' is the most suitable test to determine the experimental settings for starch gels because it has more processing application than G", particularly for starchy products (Addo et al., 2001; Hsu et al., 2000; Kasapis et al., 2000). The effect of oscillation on G' or G' was established by running frequency-dependence test. Although the G' of the blends with higher starch content was greater than G", which point to viscoelastic behavior, the G' and G" profile gap was not equal throughout the range of oscillation. Because at lower frequencies the gap between G' and G" profiles of CM gels were narrower and amplified after that. The data showed that both blends exhibited $G^{\prime}$ very dependent on starch content, since at $1.0 \mathrm{rad} / \mathrm{sec}$ the $\mathrm{G}^{\prime}$ at $40{ }^{\circ} \mathrm{C}$ of the $90 \% \mathrm{SP}$ was $3.85 \times 10^{2} \mathrm{~Pa}, 70 \%$ was $7.3 \times 10 \mathrm{~Pa}$, and the $50 \%$ was $5.1 \times 10 \mathrm{~Pa}$. However, at $25^{\circ} \mathrm{C}$ the $\mathrm{G}^{\prime}$ at $1.0 \mathrm{rad} / \mathrm{sec}$ was, $1.1 \times 10^{2} \mathrm{~Pa}, 1.5 \times 10 \mathrm{~Pa}$, and $3.2 \times 10 \mathrm{~Pa}$, for the $90 \%, 70$, and 50\%, respectively (Figure 1a, b, c, d). The viscoelastic solid-like behavior of the $90 \%$ SP is indicated by the one order magnitude reduction at lower SP content. Generally, the large G' in the presence of high SP content can be attributed to molecular entanglement, chain-chain interaction, or crosslinking, however, the shape of the G' curve presented in this study does not point to crosslinked material (Xu et al., 2006).

Therefore, only polymer chain interaction or molecular entanglement can describe the physical interaction between the SP and milk protein. Hence, more entanglement or chain to chain interaction occurred at $40^{\circ} \mathrm{C}$ that lead to higher $\mathrm{G}^{\prime}$ compared to $25^{\circ} \mathrm{C}$.

The G' of cow milk blends with SP at $40{ }^{\circ} \mathrm{C}$ exhibited, $3.7 \times 10^{2} \mathrm{~Pa}, 7.1 \times 10 \mathrm{~Pa}$ and $2.3 \times 10 \mathrm{~Pa}$ for the $90 \% \mathrm{SP}, 70 \%$ and $50 \%$, respectively, while at $25^{\circ} \mathrm{C}$ it was $1.52 \times 10^{2} \mathrm{~Pa}, 2.6 \times 10 \mathrm{~Pa}$, and $1.1 \times 10 \mathrm{~Pa}$, at $1.0 \mathrm{rad} / \mathrm{sec}$, respectively (Figure $2 \mathrm{a}, \mathrm{b}, \mathrm{c}$, and d). Generally, blends containing CWM maintained higher G' over G" like CM, but CWM revealed less solid-like behavior (lower G') compared to CA. The possible cause for the variation could be accredited to the large CM casein protein structure(Bornaz et al., 2009; Glantz et al., 2010).

Although the large casein structure was reported to be the main cause for the reduced firmness of CM coagulant, the data presented here seems to show firmer gel due to SPS and the action of urea. It is equally important to mention the contribution of gelatinized starch product (amylose and amylopectin) to the gel firmness by water immobilization. Since hydrogen bonding is the main force that holds $\mathrm{CM}$ casein molecules together, urea reduces these bonds thereby facilitates for casein molecules unfolding and become available for entanglement with starch molecules. Samples with more starch were more frequency-dependent at low oscillation frequencies because of the rapid increase in $G^{\prime}$ and G" as a function of frequency until around $1.0 \mathrm{rad} / \mathrm{sec}$. After that, gradual increase was detected at $40{ }^{\circ} \mathrm{C}$. This rapid increase at low frequencies was less evident for samples tested at $25^{\circ} \mathrm{C}$ (Figure 1a, b, c, and d) (Mohamed et al., 2019). Unlike at $40{ }^{\circ} \mathrm{C}$, the $50 \% \mathrm{CM}$ blend at $25^{\circ} \mathrm{C}$ was a lot less dependent on oscillation compared to other blends. In most cases, the profile of $\mathrm{G}^{\prime}$ of the $50 \% \mathrm{CM}$ blend plateau at $25^{\circ} \mathrm{C}$, but increased at $40^{\circ} \mathrm{C}$ as a function of frequency (Figure $3 \mathrm{a}$ and $\mathrm{b}$ ). This could identify additional points of contact between $\mathrm{CM}$ and starch components which facilitates for firmer structure and solid-like behavior as reflected by the $\mathrm{G}^{\prime}$ plateau at $25^{\circ} \mathrm{C}$ (Kamal et al., 2017). The 50\% CWM blend was dependant on frequency at both temperatures (Figure $3 \mathrm{c}$ and $\mathrm{d}$ ).

It is helpful to monitor the textural change of the gel at the beginning of oscillation as well as during oscillation, because it allows for following the coherency and the internal structure of the gel. The effect of temperatures on storage modulus (G') of the material was obvious at the beginning of the oscillation. Therefore, at the initial point of oscillation $(0.1 \mathrm{rad} / \mathrm{sec})$, the G' value of the high starch samples started about 3 times higher at $25^{\circ} \mathrm{C}$ than $40{ }^{\circ} \mathrm{C}$ for the same starch concentration, besides it was higher for the $90 \%$ SP compared to the $70 \%$ SP at the same temperature (Figure 1). This could be attributed to the formation of stronger amylose network at $25^{\circ} \mathrm{C}$, which gives the gel a solid like texture as opposed to $40{ }^{\circ} \mathrm{C}$, where higher temperature gives rise to the viscous property. Conversely, G" did not exhibit significant changes due to temperature but to a certain degree, the $70 \%$ SP reduced G" at low oscillation (Figure 1). Despite the greater $\mathrm{G}^{\prime}$ at $0.1(\mathrm{rad} / \mathrm{sec})$, the value of $\mathrm{G}^{\prime}$ of the high starch samples over the frequency range $(0.1-100 \mathrm{rad} / \mathrm{sec})$ was lesser at $25^{\circ} \mathrm{C}$ than at $40{ }^{\circ} \mathrm{C}$ (Figure 1) indicating softer gel at $25^{\circ} \mathrm{C}$. At lower frequencies, the gap between $\mathrm{G}^{\prime}$ and $\mathrm{G}^{\prime}$ of the high starch/CM blends was much narrower at $40^{\circ} \mathrm{C}$ compared to $25^{\circ} \mathrm{C}$ (Figure 1a and b), however, at higher frequencies the gap was even smaller. Greater frequencies and $25^{\circ} \mathrm{C}$ appeared to reduce the $G^{\prime}$ and increase $G^{\prime \prime}$ indicating the domination of viscosity over elasticity (Figure 1a and c). Consequently, higher frequencies have an adverse effect on the high starch gels.

High starch samples/CWM blends presented profiles with frequency-dependence at low frequencies because of the quick increase in both $\mathrm{G}^{\prime}$ and G", particularly at $40^{\circ} \mathrm{C}$ (Figure $2 \mathrm{a}$ and b). The profile gap between the G' and G" of CWM blends was larger 
Fig la. Dynamic frequency sweep at $5 \%$ shear strain of $90 \%$ sweet potato starch (SPS) and 10\% camel milk (CAM) in $2 \mathrm{M}$ urea solution at $40^{\circ} \mathrm{C}$

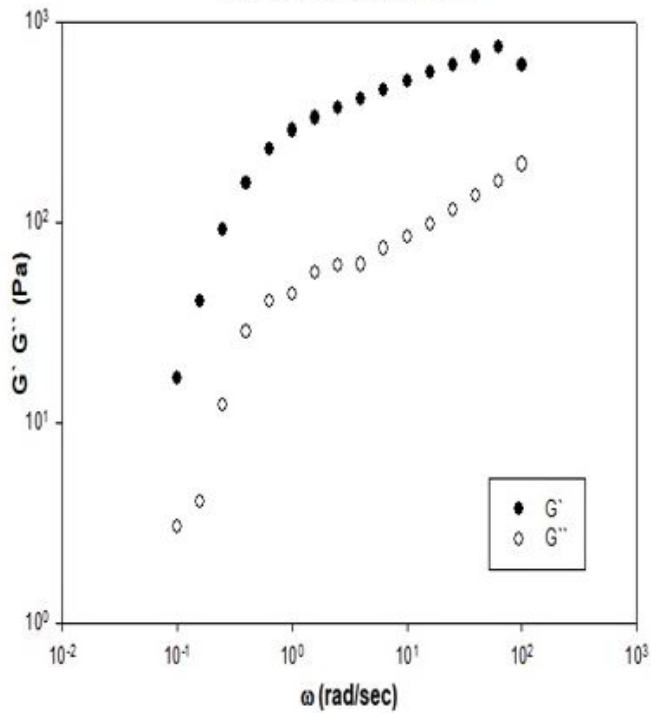

Fig 1c. Dynamic frequency sweep at $5 \%$ shear strain of $90 \%$ sweet potato starch (SPS) and 10\% camel milk (CAM) in $2 \mathrm{M}$ urea solution at $25^{\circ} \mathrm{C}$

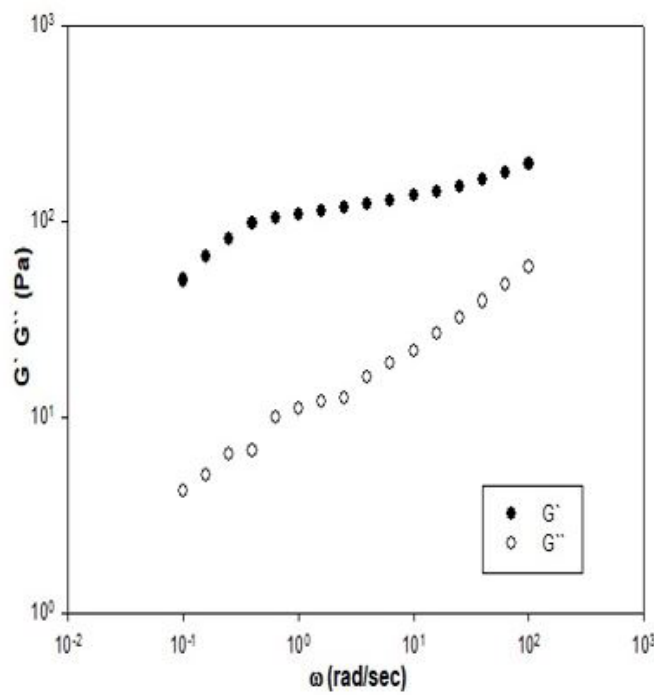

Fig 1b. Dynamic frequency sweep at $5 \%$ shear strain of $70 \%$ sweet potato starch (SPS) and $30 \%$ camel milk (CAM) in $2 \mathrm{M}$ urea solution at $40^{\circ} \mathrm{C}$

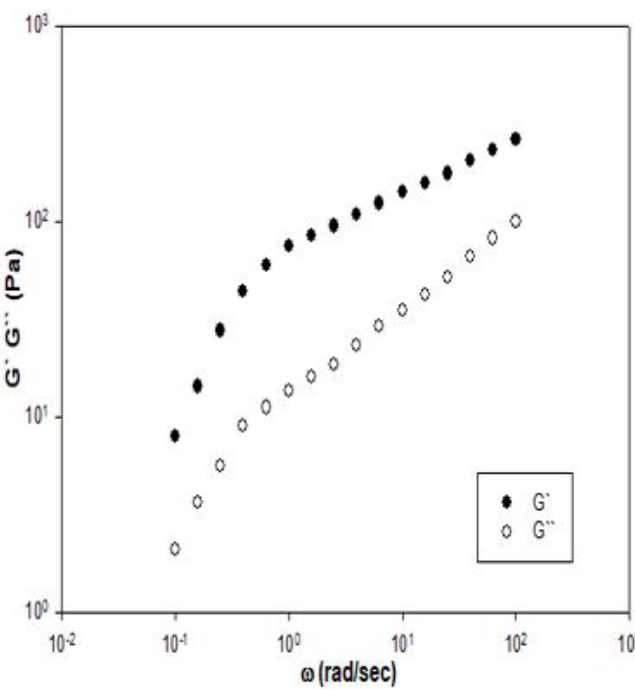

Fig 1d. Dynamic frequency sweep at $5 \%$ shear strain of $70 \%$ sweet potato starch (SPS) and $30 \%$ camel milk (CAM) in $2 \mathrm{M}$ urea solution at $25^{\circ} \mathrm{C}$

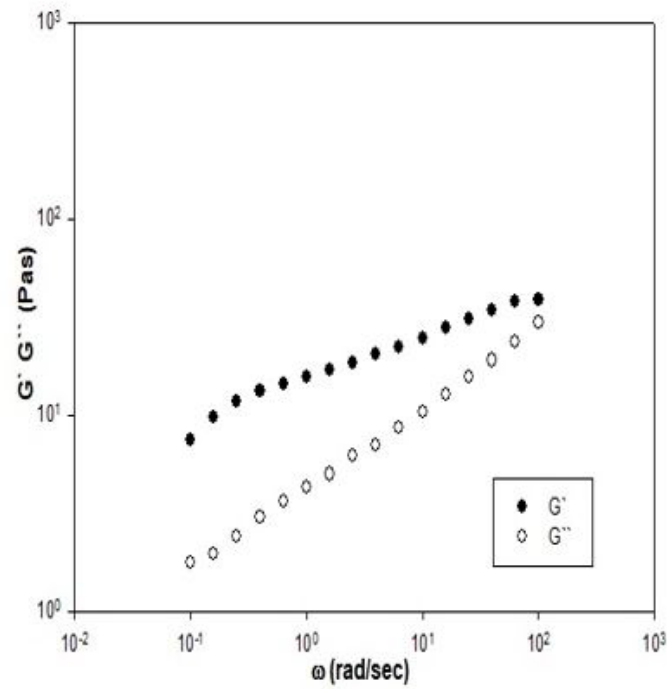

Figure 1. 1a - Dynamic frequency sweep at 5\% shear strain of $90 \%$ sweet potato starch (SPS) and 10\% camel milk (CAM) in 2 M urea solution at $40^{\circ} \mathrm{C} .1 \mathrm{~b}$ - Dynamic frequency sweep at $5 \%$ shear strain of $70 \%$ sweet potato starch (SPS) and $30 \%$ camel milk (CAM) in $2 \mathrm{M}$ urea solution at $40^{\circ} \mathrm{C}$. $1 \mathrm{c}$ - Dynamic frequency sweep at $5 \%$ shear strain of $90 \%$ sweet potato starch (SPS) and $10 \%$ camel milk (CAM) in $2 \mathrm{M}$ urea solution at $25^{\circ} \mathrm{C}$. $1 \mathrm{~d}$ - Dynamic frequency sweep at $5 \%$ shear strain of $70 \%$ sweet potato starch (SPS) and $30 \%$ camel milk (CAM) in $2 \mathrm{M}$ urea solution at $25^{\circ} \mathrm{C}$.

at $25^{\circ} \mathrm{C}$ at the start of oscillation compared to $40{ }^{\circ} \mathrm{C}$, specifically for the $70 \%$ starch blend (Figure $2 \mathrm{c}$ and $\mathrm{d}$ ). The domination of $\mathrm{G}^{\prime}$ at $25^{\circ} \mathrm{C}$ at lower frequencies indicates solid-like texture. Nevertheless, $G^{\prime}$ reached plateau as the frequency increased (Figure 2c). Since the material had more stable structure at elevated oscillation, this property can be used as processing tool. Therefore, both milk blends have stable texture at higher starch content and elevated frequencies at $40{ }^{\circ} \mathrm{C}$ by virtue of slower decrease in $\mathrm{G}^{\prime}$ (Figure 1 and 2). In addition, milk blends with high starch content have typical solid-like texture, which is evident on the stability and the slope of $\mathrm{G}^{\prime}$ as a function of oscillation intensity at $40{ }^{\circ} \mathrm{C}$. The solid-like texture can be attributed to the amylose network and its ability to immobilize water. movement within the gel.

\section{Equal amount of milk and SP}

The G' of blends prepared with equal amounts of SP starch and camel milk (CM), between 0.1 and 1.0 frequencies ( $\mathrm{rad} / \mathrm{esc}$ ) 
Fig 2a. Dynamic frequency sweep at $5 \%$ shear strain of $90 \%$ sweet potato starch (SPS) and $10 \%$ cow milk (COM) in $2 \mathrm{M}$ urea solution at $40^{\circ} \mathrm{C}$

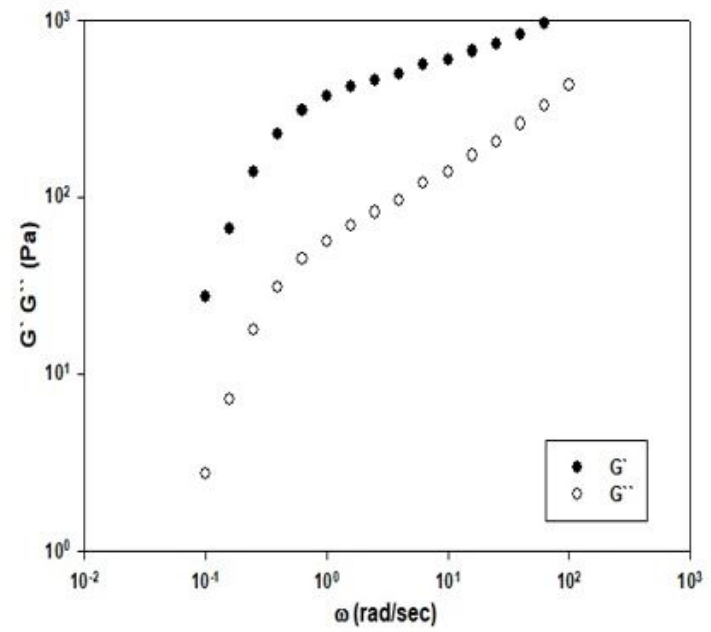

Fig 2c. Dynamic frequency sweep at $5 \%$ shear strain of $90 \%$ sweet potato starch (SPS) and $10 \%$ cow milk (COM) in $2 \mathrm{M}$ urea solution at $25^{\circ} \mathrm{C}$

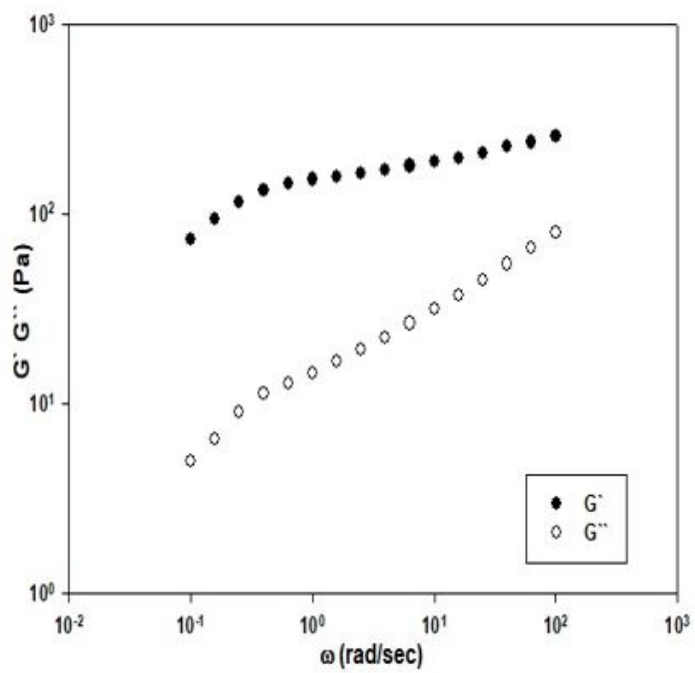

Fig $2 b$. Dynamic frequency sweep at $5 \%$ shear strain of $70 \%$ sweet potato starch (SPS) and 30\% cow milk (COM) in $2 \mathrm{M}$ urea solution at $40^{\circ} \mathrm{C}$

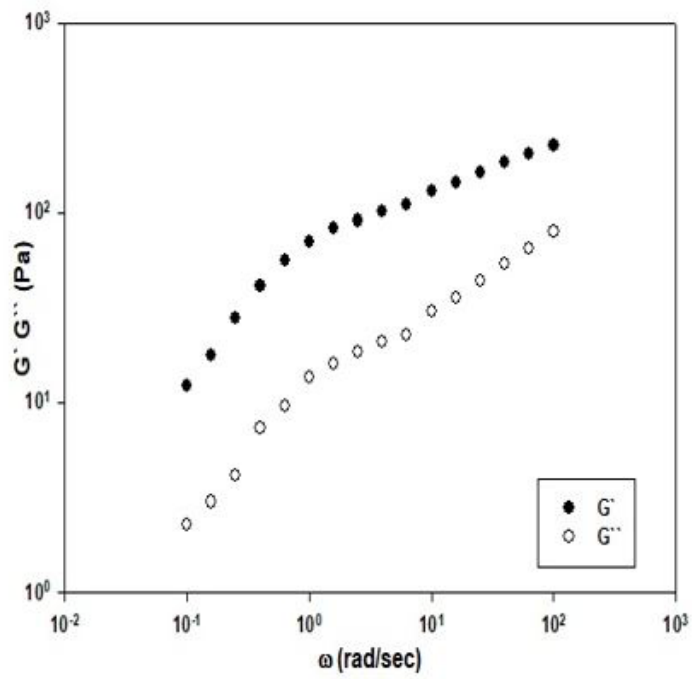

Fig 2d. Dynamic frequency sweep at $5 \%$ shear strain of $70 \%$ sweet potato starch (SPS) and $30 \%$ cow milk (CAM) in $2 \mathrm{M}$ urea solution at $25^{\circ} \mathrm{C}$

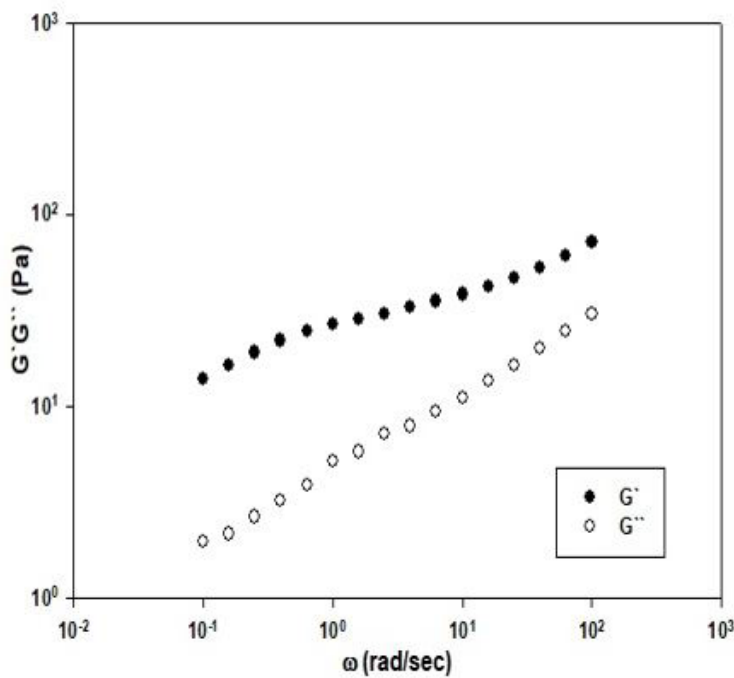

Figure 2. 2a - Dynamic frequency sweep at $5 \%$ shear strain of $90 \%$ sweet potato starch (SPS) and $10 \%$ cow milk (COM) in $2 \mathrm{M}$ urea solution at $40^{\circ} \mathrm{C}$. $2 \mathrm{~b}$ - Dynamic frequency sweep at $5 \%$ shear strain of $70 \%$ sweet potato starch (SPS) and $30 \%$ cow milk (COM) in $2 \mathrm{M}$ urea solution at $40^{\circ} \mathrm{C} .2 \mathrm{c}$ - Dynamic frequency sweep at $5 \%$ shear strain of $90 \%$ sweet potato starch (SPS) and $10 \%$ cow milk (COM) in $2 \mathrm{M}$ urea solution at $25^{\circ} \mathrm{C}$. $2 \mathrm{~d}$ - Dynamic frequency sweep at $5 \%$ shear strain of $70 \%$ sweet potato starch (SPS) and $30 \%$ cow milk (COM) in $2 \mathrm{M}$ urea solution at $25^{\circ} \mathrm{C}$.

was 8 times greater than $G^{\prime \prime}$ and decreased at elevated frequencies due to surge in G" as a function of increased oscillation (Figure 3). After $1.0(\mathrm{rad} / \mathrm{sec})$, the influence of temperature on the difference between G' and G' was obvious. On the other hand, the G' of $\mathrm{CM}$ at $0.1(\mathrm{rad} / \mathrm{sec})$ was triple that of CWM, reflecting far more elasticity. Conversely, the G' of the $50 \%$ CWM was 4 times greater than G" for both 0.1 or 1.0 ( $\mathrm{rad} / \mathrm{sec})$, but the profile gap between G' and G" was slimmer at higher frequencies. Consequently, the shape of G' and G" profiles of both milk blends was similar but the magnitude differs, because G' of CM was 3 times higher than CWM (more elastic). This difference was obvious in the parameters of other results discussed earlier.

\section{High milk samples}

The rheological profiles of these blends are shown in Figure 4. The G' of the $90 \%$ milk blends of each CM or CWM exhibited low G' particularly at low frequency. These blends were very oscillation-dependant and maintained constant increase in $\mathrm{G}^{\prime}$ 
Fig 3a. Dynamic frequency sweep at $5 \%$ shear strain of $50 \%$ sweet potato starch (SPS) and 50\% camel milk (CAM) in $2 \mathrm{M}$ urea solution at $25^{\circ} \mathrm{C}$

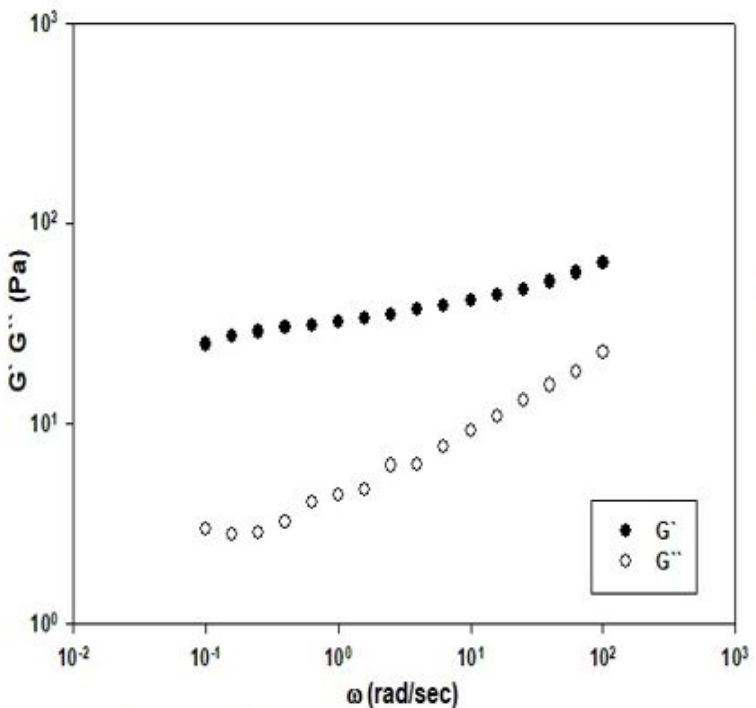

Fig 3c. Dynamic frequency sweep at 5\% shear strain of $50 \%$ sweet potato starch (SPS) and $50 \%$ cow milk (COM) in $2 \mathrm{M}$ urea solution at $25^{\circ} \mathrm{C}$

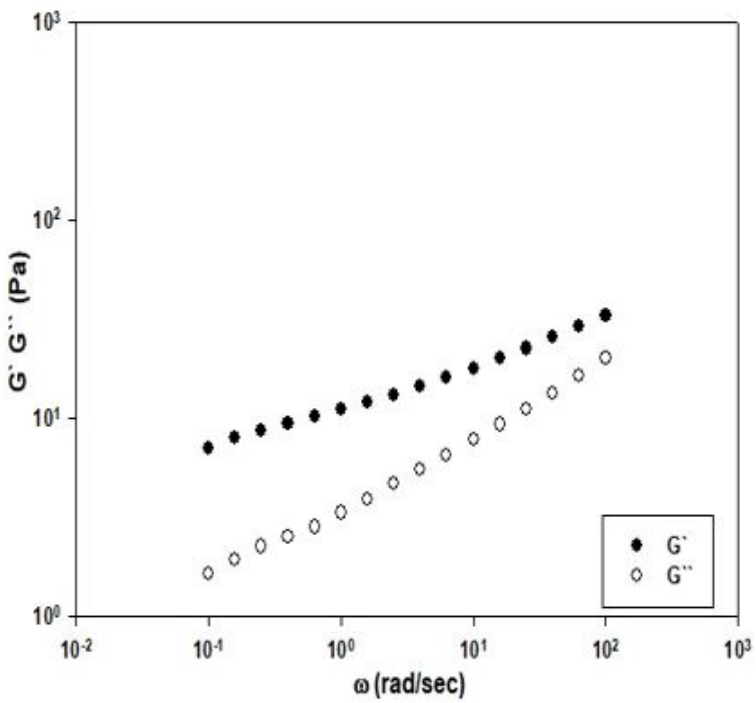

Fig 3b. Dynamic frequency sweep at $5 \%$ shear strain of $50 \%$ sweet potato starch (SPS) and $50 \%$ camel milk (CAM) in $2 \mathrm{M}$ urea solution at $40^{\circ} \mathrm{C}$

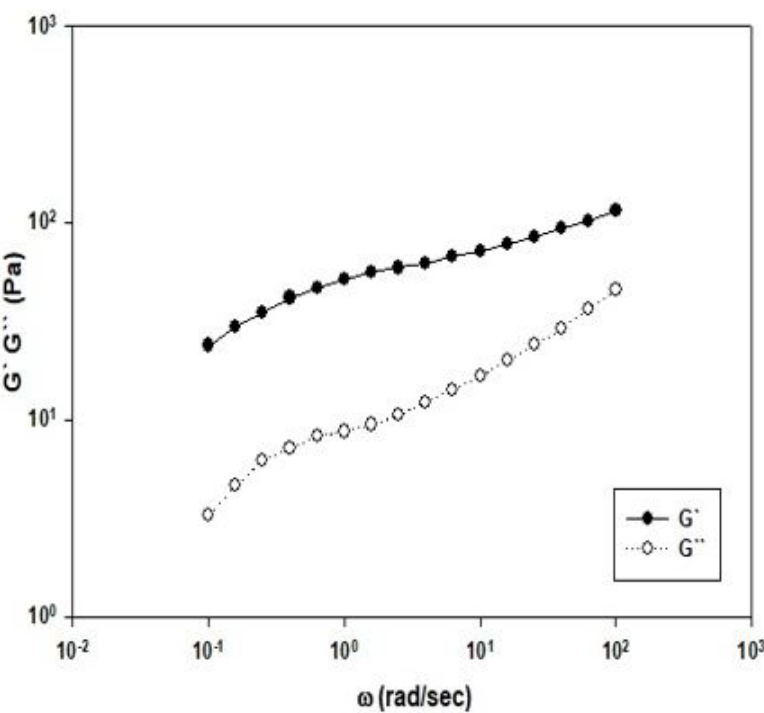

Fig 3d. Dynamic frequency sweep at $5 \%$ shear strain of $50 \%$ sweet potato starch (SPS) and $50 \%$ cow milk (COM) in $2 \mathrm{M}$ urea solution at $40^{\circ} \mathrm{C}$

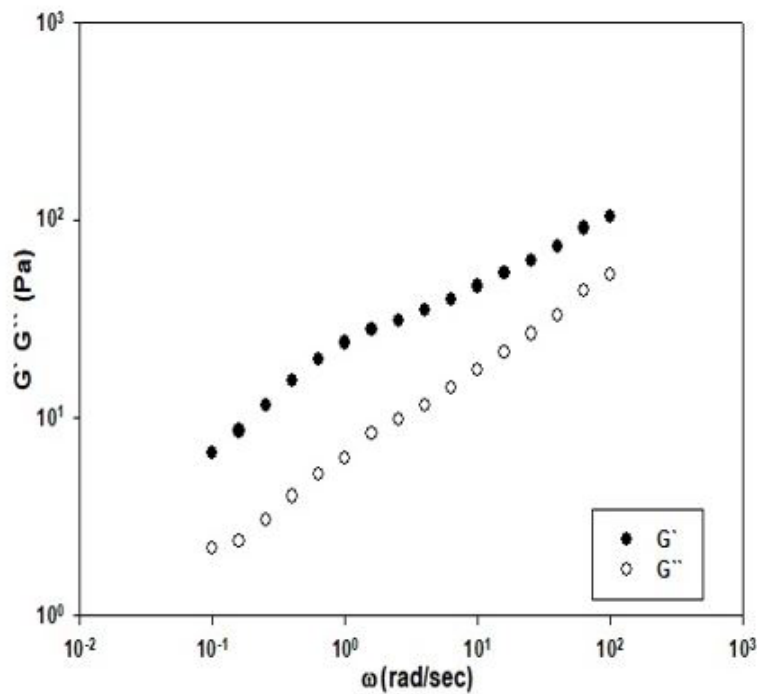

Figure 3. 3a - Dynamic frequency sweep at 5\% shear strain of 50\% sweet potato starch (SPS) and 50\% camel milk (CAM) in 2 M urea solution at $25^{\circ} \mathrm{C} .3 \mathrm{~b}$ - Dynamic frequency sweep at $5 \%$ shear strain of $50 \%$ sweet potato starch (SPS) and $50 \%$ camel milk (CAM) in $2 \mathrm{M}$ urea solution at 400C. 3c - Dynamic frequency sweep at 5\% shear strain of 50\% sweet potato starch (SPS) and 50\% cow milk (CAM) in $2 \mathrm{M}$ urea solution at $25^{\circ} \mathrm{C} .3 \mathrm{~d}$ - Dynamic frequency sweep at $5 \%$ shear strain of $50 \%$ sweet potato starch (SPS) and $50 \%$ cow milk (CAM) in $2 \mathrm{M}$ urea solution at $40^{\circ} \mathrm{C}$.

and G" as a function of higher oscillation and showed no sign for plateau. At low oscillation, the material did not maintain one specific rheological behavior because it was shifting between elastic or viscous behavior (profile is not shown). However, for the same concentration, CM exhibited elastic behavior whereas CWM was more viscous. Unlike the 90\% milk, the $70 \%$ milk blends sustained steady viscoelastic behavior as reflected on 2 to 4 times higher G' than G". The solid-like texture of the high CM content blends appeared to be oscillation and temperature-dependent as presented by the large difference between G' and G' including G' slope (Figure 4). This behavior was noticed for samples high in starch content as discussed previously and presumed to be due to amylose network. Once again, G' and G" differences at low oscillation frequency was more noticeable for the $\mathrm{CM}$ at $40^{\circ} \mathrm{C}$ but the opposite was true at higher oscillation (Figure $4 \mathrm{a}$ and $\mathrm{b}$ ). Regardless of temperature, 
Fig $4 a$. Dynamic frequency sweep at $5 \%$ shear strain of 30\% sweet potato starch (SPS) and 70\% camel milk (CAM) in $2 \mathrm{M}$ urea solution at $25^{\circ} \mathrm{C}$

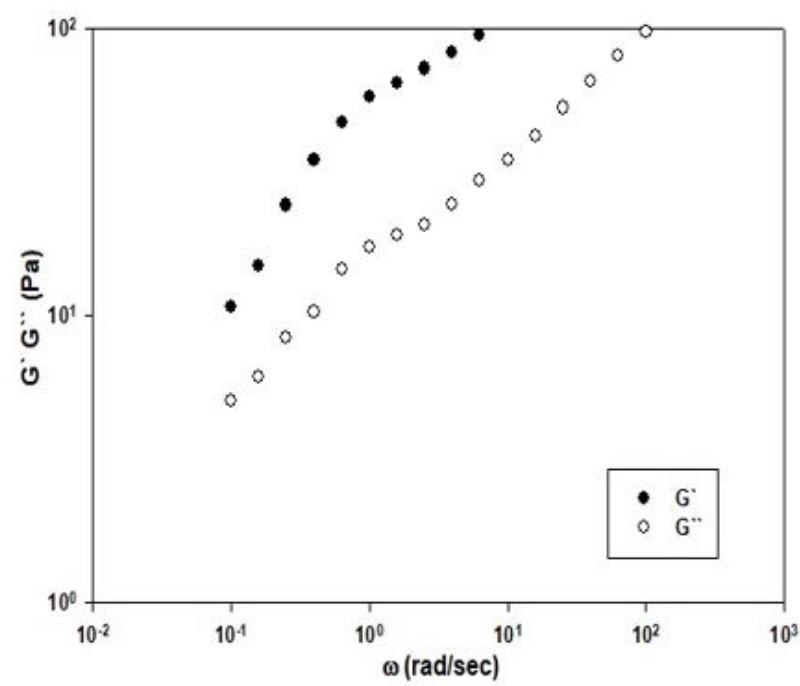

Fig 4c. Dynamic frequency sweep at $5 \%$ shear strain of $30 \%$ sweet potato starch (SPS) and 70\% cow milk (COM) in $2 \mathrm{M}$ urea solution at $25^{\circ} \mathrm{C}$

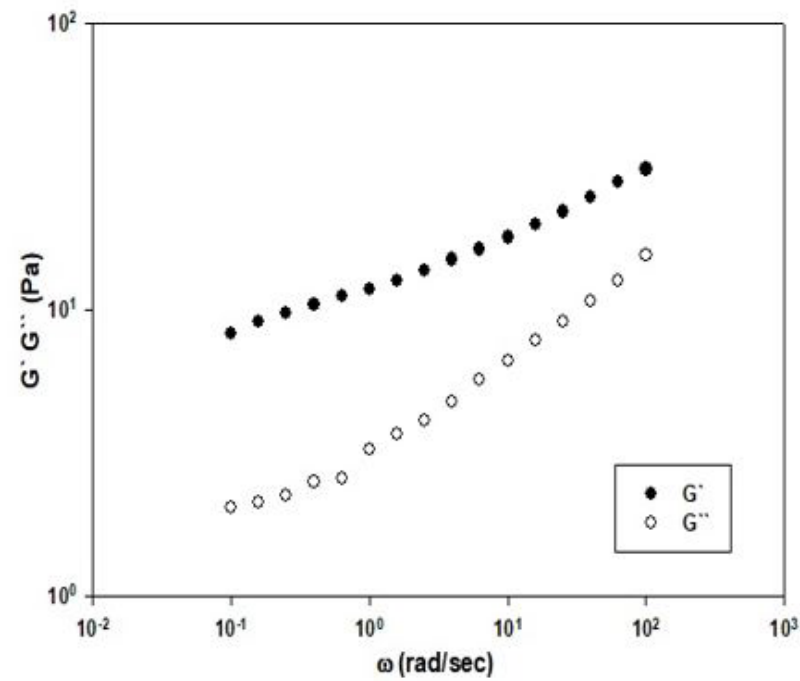

Fig $4 \mathrm{~b}$. Dynamic frequency sweep at $5 \%$ shear strain of $30 \%$ sweet potato starch (SPS) and $70 \%$ camel milk (CAM) in $2 \mathrm{M}$ urea solution at $40^{\circ} \mathrm{C}$

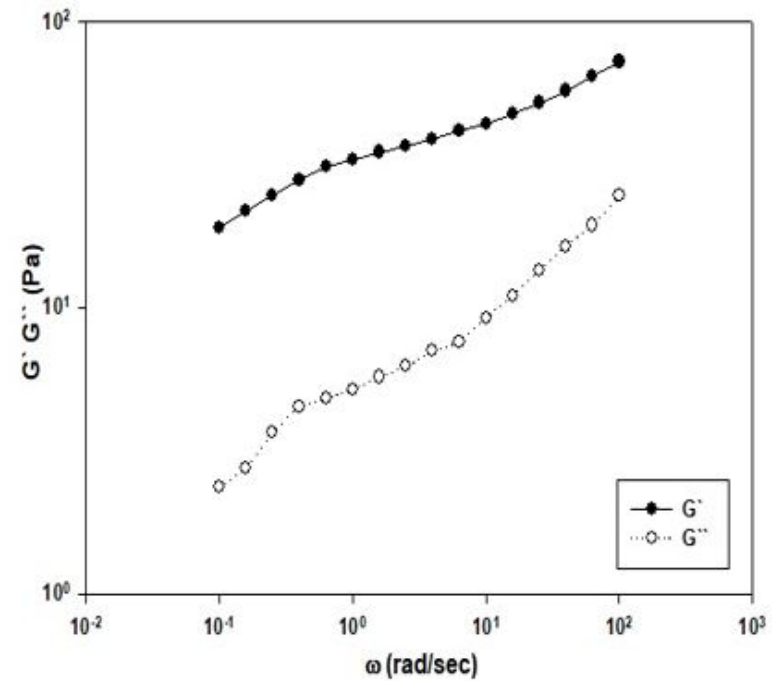

Fig $4 d$. Dynamic frequency sweep at $5 \%$ shear strain of $30 \%$ sweet potato starch (SPS) and 70\% cow milk (COM) in $2 \mathrm{M}$ urea solution at $40^{\circ} \mathrm{C}$

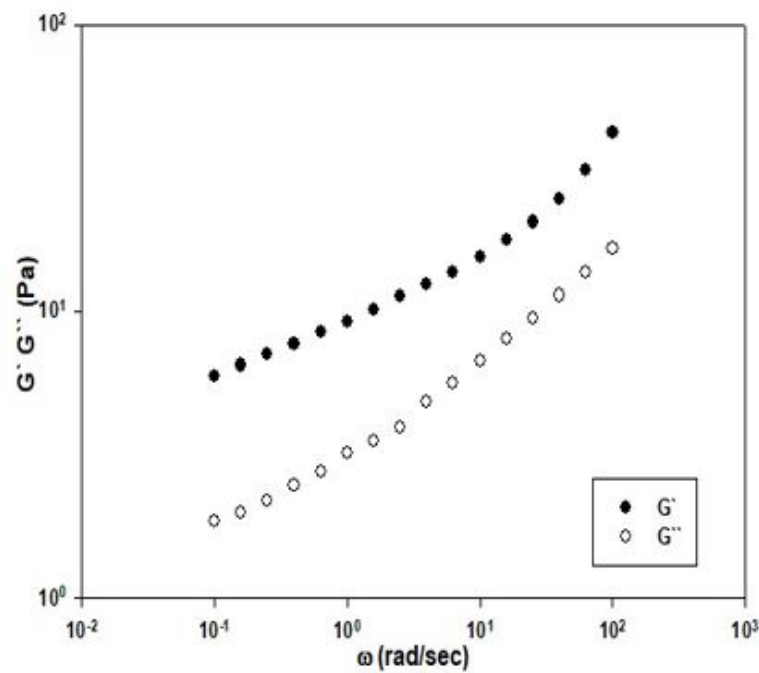

Figure 4. $4 \mathrm{a}$ - Dynamic frequency sweet at $5 \%$ shear strain of $30 \%$ sweet potato starch (SPS) and 70\% camel milk (CAM) in $2 \mathrm{M}$ urea solution at $25^{\circ} \mathrm{C} .4 \mathrm{~b}$ - Dynamic frequency sweet at $5 \%$ shear strain of $30 \%$ sweet potato starch (SPS) and 70\% camel milk (CAM) in $2 \mathrm{M}$ urea solution at 400C. 4c - Dynamic frequency sweet at 5\% shear strain of 30\% sweet potato starch (SPS) and 70\% cow milk (CAM) in $2 \mathrm{M}$ urea solution at $25^{\circ} \mathrm{C} .4 \mathrm{~d}$ - Dynamic frequency sweet at $5 \%$ shear strain of $30 \%$ sweet potato starch (SPS) and $70 \%$ cow milk (CAM) in $2 \mathrm{M}$ urea solution at $40^{\circ} \mathrm{C}$.

G' and G' of the high CWM blends did not change as much with increase in oscillation (Figure $4 \mathrm{c}$ and $\mathrm{d}$ ). This may explain the basic molecular structural variation between CM and CWM with respect to the casein protein molecular size and its capacity to interact with the gelatinized starch, mainly at $40^{\circ} \mathrm{C}$ (Glantz et al., 2010). At $1.0 \mathrm{rad} / \mathrm{sec}$, the $\mathrm{G}^{\prime} \mathrm{CM}$ blends were 3 folds greater than G" at $25^{\circ} \mathrm{C}$ and 6 times more at $40^{\circ} \mathrm{C}$, while the G' of CWM was triple G" for both temperatures (Figure 4). Therefore, higher CM blends exhibited elastic texture at higher temperatures which could be attributed to molecular mobility of casein which increased chances for interaction with starch components (amylose or amylopectin). At the same content, camel milk gel elasticity was superior compared with CWM by virtue of G' domination at the start of the oscillation $(0.1 \mathrm{rad} / \mathrm{sec})$. The opening up of casein protein of $\mathrm{CM}$ by reducing the intra hydrogen bonding (by urea) 
allowed for molecular entanglement with starch components and the extended casein polypeptide of CA.

\section{Storage modulus slope}

In Table 1, the slopes of $\mathrm{G}$ ' as a function of frequency were calculated to determine and compare the properties of CM and CWM gels at similar sweet potato starch content. The slope was calculated for blends prepared from 10, 30, 50, 70, and 90\% milk content. Obviously, higher positive G' slope is a sign of structural changes at higher frequencies. The slopes of the high milk content blends increased at higher frequency indicating significant gel structural changes, whereas low slope is a sign of stability during oscillation, hence coherent gel structure. Samples with higher than $50 \%$ milk content didn't exhibit specific slope pattern (Table 1). The temperature appeared to be an important factor that causes significant change on the slope at higher SP content,

Table 1. Slopes of the storage modulus (G') as a function of oscillation $(\mathrm{rad} / \mathrm{sec})$ of Camel milk or CWM milk + sweet potato starch (SP) at 90, 70, 50, 30, and $10 \%(\mathrm{w} / \mathrm{w})$ milk at $25^{\circ} \mathrm{C}$ and $40^{\circ} \mathrm{C}$.

\begin{tabular}{ccccc}
\hline Milk type & $\begin{array}{c}\text { Temperature } \\
\left({ }^{\circ} \mathrm{C}\right)\end{array}$ & \% Milk & G'slope & $\mathrm{R}^{2}$ \\
\hline Camel & 25 & 90 & 0.69 & 0.90 \\
milk & & 70 & 0.39 & 0.94 \\
& & 50 & 0.12 & 0.97 \\
& 30 & 0.22 & 0.92 \\
& 10 & 0.16 & 0.99 \\
& 40 & 90 & 0.43 & 0.93 \\
& & 70 & 0.17 & 0.98 \\
Cow milk & 50 & 0.20 & 0.99 \\
& & 30 & 0.42 & 0.91 \\
& & 10 & 0.43 & 0.77 \\
& & 90 & 0.89 & 0.91 \\
& & 70 & 0.17 & 0.94 \\
& & 50 & 0.22 & 0.97 \\
& & 30 & 0.21 & 0.91 \\
& & 10 & 0.14 & 0.98 \\
& 40 & 90 & 0.75 & 0.91 \\
& & 70 & 0.26 & 0.86 \\
& & 50 & 0.37 & 0.99 \\
& & 30 & 0.38 & 0.92 \\
& & 0.41 & 0.82 \\
\hline
\end{tabular}

$1=\mathrm{R}^{2}=$ Coefficient of determination because at $40{ }^{\circ} \mathrm{C}$ the slopes were closer in values regardless of milk type or content (Table 1). Temperature impact on other gel rheological properties was obvious as discussed earlier. This was reflected on the gel texture at higher milk content as it will be discussed later. As shown by other parameters presented above; camel milk slopes were lower than CWM milk, which indicates stable gel structure.

\section{The $\tan \delta$}

The $\tan \delta\left(=G^{\prime \prime} / G^{\prime}\right)$ describes the relationship between the viscous and elastic portions of gels. Regardless of temperatures, composition or concentrations, the $\tan \delta$ was $<1.0$ for all blends which suggests solid-like texture with distinct differences between gels. The $\tan \delta$ of high starch blends with CWM increased gradually as a function of frequency. Blends with $90 \% \mathrm{SP} / 10 \%$ CWM exhibited maximum $\tan \delta$ as 0.31 and 0.42 at $25{ }^{\circ} \mathrm{C}$, whereas $70 \% \mathrm{SP} / 30 \% \mathrm{CWM}$ showed maximum $\tan \delta$ as 0.39 and 0.35 at $40{ }^{\circ} \mathrm{C}$. Greater $\tan \delta$ is caused by a drop in G' at higher frequencies which represents gels with reduced elasticity. It is apparent how the temperature and SP level can affect $\tan \delta$ values, since $90 \% \mathrm{SP}$ at $25^{\circ} \mathrm{C}$ showed more elastic material than viscous, by virtue of lower $\tan \delta$ compared to higher temperature and low SP content. Conversely, CM milk gels presented drop in tan $\delta\left(\right.$ at $\left.40{ }^{\circ} \mathrm{C}\right)$ at lower frequencies between 0.1 and $1.0(\mathrm{rad} / \mathrm{sec})$ followed by steady increased, which means that these gels were more elastic at lower frequencies. However, the maximum $\tan \delta$ of $90 \%$ and $70 \%$ SP blends with CA at $25^{\circ} \mathrm{C}$ was 0.77 and 0.30 , respectively, whereas 0.32 and 0.39 was recorded for the $40{ }^{\circ} \mathrm{C}$ for both SP levels. This indicates higher viscosity of CA blends at $25^{\circ} \mathrm{C}$ compared to $40{ }^{\circ} \mathrm{C}$ and the $90 \%$ SP compared to $70 \%$ SP. The lower $\tan \delta$ was expected because higher temperature increased the G' of CA gels as discussed earlier. The high milk content samples presented a weak gel with minimum elasticity and high $\tan \delta$, especially samples with $90 \%$ CWM, whereas the $70 \%$ and 50\% CWM exhibited better elasticity (lower $\tan \delta$ ). A drop in $\tan \delta$ at lower frequencies was observed which indicates more elastic gel, but it increased again signifying more viscous behavior. High CM blends at $40^{\circ} \mathrm{C}$ showed elastic property at frequencies between 0.1 and $1.5(\mathrm{rad} / \mathrm{sec})$ followed by viscus behavior at higher frequencies. The variations between the two milks was evident in $\tan \delta$ profiles where $\mathrm{CM}$ appeared to sustain elastic property at least at low oscillation $(0.12-1.5 \mathrm{rad} / \mathrm{sec})$ for all starch content regardless temperatures. In the most part, the G' of CA blends was more dominate than CWM. The data

Table 2. Power law model fitted parameters of camel milk and CWM milk at $25^{\circ} \mathrm{C}$ and $40{ }^{\circ} \mathrm{C}$.

\begin{tabular}{|c|c|c|c|c|c|c|c|c|c|c|c|c|}
\hline \multirow{3}{*}{ \%Milk } & \multicolumn{6}{|c|}{ Camel milk } & \multicolumn{6}{|c|}{ CWM milk } \\
\hline & \multicolumn{3}{|c|}{$25^{\circ} \mathrm{C}$} & \multicolumn{3}{|c|}{$40^{\circ} \mathrm{C}$} & \multicolumn{3}{|c|}{$25^{\circ} \mathrm{C}$} & \multicolumn{3}{|c|}{$40^{\circ} \mathrm{C}$} \\
\hline & $K^{\mathrm{a}}$ & $n^{\mathrm{b}}$ & $\mathrm{R}^{2}$ & $K$ & $n$ & $\mathrm{R}^{2}$ & $K$ & $n$ & $\mathrm{R}^{2}$ & $K$ & $n$ & $\mathrm{R}^{2}$ \\
\hline 90 & 0.95 & 0.56 & 0.96 & 0.55 & 0.48 & 0.98 & 1.45 & 0.88 & 0.92 & 0.98 & 0.68 & 0.97 \\
\hline 70 & 1.16 & 0.41 & 0.99 & 0.70 & 0.31 & 0.99 & 0.53 & 0.31 & 0.99 & 0.52 & 0.32 & 0.99 \\
\hline 50 & 0.67 & 0.32 & 0.99 & 0.93 & 0.34 & 0.99 & 0.54 & 0.36 & 0.99 & 0.78 & 0.47 & 0.99 \\
\hline 30 & 0.99 & 0.41 & 0.99 & 1.63 & 0.51 & 0.97 & 0.67 & 0.39 & 0.99 & 0.39 & 0.67 & 0.99 \\
\hline 10 & 0.63 & 0.37 & 0.99 & 1.04 & 0.32 & 0.99 & 1.14 & 0.37 & 0.97 & 0.37 & 1.14 & 0.99 \\
\hline
\end{tabular}

${ }^{A} K=$ constant; ${ }^{\mathrm{b}} n=$ power law exponent. 
presented here indicated that CWM gels undergo major physical changes at $40{ }^{\circ} \mathrm{C}$.

\subsection{Nonlinear steady shear}

Nonlinear steady shear testing was done to determine the response of SP/CM or CWM gels pertained to temperature and blend composition. Obviously, all blends exhibited shearthinning profiles within the tested shear rate where at higher solid content the viscosities were higher (no precipitation). The viscosities profiles as a function of shear rate of the high milk samples showed that higher milk content caused significant drop in the viscosity especially at $90 \%$ milk content. The viscosity of CM was higher than CWM for the same temperature and solid content. This is in agreement with the behavior of CM revealed by other tests, as stated earlier. The viscosity profile of $\mathrm{CM}$ was more solid content-dependent than CWM, but higher sweet potato content (less milk content) instigated increase in viscosity. Conversely, the viscosity of CWM blends was less solid content-dependent at $25^{\circ} \mathrm{C}$. The level of viscosity at $25^{\circ} \mathrm{C}$ and $40{ }^{\circ} \mathrm{C}$ was comparable for both milk blends, but at $40{ }^{\circ} \mathrm{C}$ the viscosities were dependent on the solid content. The effect of temperature on the slope of viscosity of the blends was more noticeable than the effect of shear rate. The power law has direct application on characterizing shear thinning behavior of the blends according to Equation 1.

$\eta=k \gamma^{n-1}$

where $\eta$ is the shear viscosity, $k$ is the constant, $\gamma$ is shear rate, and $n$ is power law exponent. The data of Equation 1 is listed in Table 2.

Blends with more milk content exhibited higher power law exponent with the exceptions of $30 \% \mathrm{CM}$ at $25{ }^{\circ} \mathrm{C}$ and $40{ }^{\circ} \mathrm{C}$ (Table 2). Samples with $10 \%$ milk content exhibited lower exponents than those with the most milk content (90\%) except for $\mathrm{CWM}$ at $40^{\circ} \mathrm{C}$ (Table 2). The trend of power law exponent shift is in agreement with the effect of the solid content on the slope of the viscoelastic component mentioned above and listed in Table 1. Overall, samples with $<90 \%$ milk content appeared to have increasing exponent at lower milk content. This indicates changes in structure of the gel which may be due to chains interaction or molecular entanglement because the shape of G' curves (discussed earlier) did not indicate crosslinking profile. Similar behavior of legume protein-concentrate was reported (Xu et al., 2006). Therefore, the theory of chain-chain entanglement is the closest justification for the higher exponent of blends $<$ $70 \%$ and $>30 \%$ milk content. Usually, such materials flow easier under applied shear because the internal structure network is weakened or broken down. The difference between CM and CWM is evident when we consider the power law exponent value, where the $n$ value was lower for CM. Consequently, $\mathrm{CM}$-containing blends exhibited stronger structure (low $n$ and high G') while CWM showed stronger shear thinning behavior by virtue of the higher $n$ value. This behavior was observed for tapioca starch when combined with different polysaccharides and can be used to predict the behavior of the blend during processing (Fuongfuchat et al., 2012).

\subsection{Gel texture}

Gel hardness was another experiment used to show how milk and SP interact. Camel milk gels were harder than CWM gel after overnight storage at room temperature. The gel hardness of the $10 \%, 30 \%$, and $50 \% \mathrm{CM}$ was $133,47,9.7 \mathrm{~g}$, respectively, whereas CWM exhibited 109, 28, and $13 \mathrm{~g}$. This data is in agreement with the superior rheological properties of CM over CWM.

\section{Conclusions}

Dynamic rheological tests of precooked sweet potatofortified camel milk and cow milk gels were performed and the results showed that camel milk exhibited more elastic behavior at $40^{\circ} \mathrm{C}$ compared to CWM milk. CM gels had harder texture with major difference between G' and G" profiles and frequencydependent at lower frequencies, in addition to lower $\tan \delta$. CWM exhibited grater G' slopes as a function of oscillation frequency compared to camel milk which indicates obvious looser structure. The lower power law exponent $(n)$ value of CM blends indicates coherent gel while CWM exhibited more shear thinning due to the higher $n$ value. This difference can be used to predict samples processing conditions. The outcome of this work showed that the use of urea caused casein to open up and interact with gelatinized starch and produce gels with more elastic properties. This data introduces a new approach to expand camel milk utilization.

\section{Acknowledgements}

The authors extend their appreciation to the Deanship of Scientific Research at King Saud University for funding this work through research group no. RG-1441-405.

\section{References}

Abd Karim, A., Norziah, M., \& Seow, C. (2000). Methods for the study of starch gelatinisation. Food Chemistry, 71(1), 9-36. http://dx.doi. org/10.1016/S0308-8146(00)00130-8.

Abdulqadr, A. T., Sebo, N. H., \& Mahmood, K. T. (2014). Effect of microbial transglutaminase addition on some physical, chemical and sensory properties of goat's milk yogurt. ZANCO Journal of Pure and Applied Sciences, 27(1), 19-30.

Abou-Soliman, N. H. I., Awad, S., \& Desouky, M. M. (2020). Effect of digestive enzymes on the activity of camel-milk insulin. International Journal of Dairy Technology, 73(2), 341-344. http:// dx.doi.org/10.1111/1471-0307.12680.

Abu-Lehia, I. (1987). Composition of camel milk. Milchwissenschaft. Milk Science International, 42, 368.

Abu-Tarboush, H. (1996). Comparison of associative growth and proteolytic activity of yogurt starters in whole milk from camels and cows. Journal of Dairy Science, 79(3), 366-371. http://dx.doi. org/10.3168/jds.S0022-0302(96)76373-7.

Addo, K., Xiong, Y., \& Blanchard, S. (2001). Thermal and dynamic rheological properties of wheat flour fractions. Food Research International, 34(4), 329-335. http://dx.doi.org/10.1016/S09639969(00)00171-X.

Al Haj, O. A., \& Al Kanhal, H. (2010). Compositional, technological and nutritional aspects of dromedary camel milk. International Dairy Journal, 20(12), 811-821. http://dx.doi.org/10.1016/j.idairyj.2010.04.003. 
Alamri, M., Hussain, S., Mohamed, A., Abdo Qasem, A. A., \& Ibraheem, M. (2016). A study on the effect of black cumin extract on the swelling power, textural, and pasting properties of different starches. Stärke, 68(11-12), 1233-1243. http://dx.doi.org/10.1002/star.201500330.

Al-Hashem, F. (2009). Camel's milk protects against aluminum chloride-induced toxicity in the liver and kidney of white albino rats. American Journal of Biochemistry and Biotechnology, 5(3), 98108. http://dx.doi.org/10.3844/ajbbsp.2009.98.108.

Al-Zoreky, N. S., \& Al-Otaibi, M. M. (2015). Suitability of camel milk for making yogurt. Food Science and Biotechnology, 24(2), 601-606. http://dx.doi.org/10.1007/s10068-015-0078-z.

Berhe, T., Ipsen, R., Seifu, E., Kurtu, M. Y., Eshetu, M., \& Hansen, E. B. (2018). Comparison of the acidification activities of commercial starter cultures in camel and bovine milk. LWT, 89, 123-127. http:// dx.doi.org/10.1016/j.lwt.2017.10.041.

Bornaz, S., Sahli, A., Attalah, A., \& Attia, H. (2009). Physicochemical characteristics and renneting properties of camels' milk: a comparison with goats', ewes' and cows' milks. International Journal of Dairy Technology, 62(4), 505-513. http://dx.doi.org/10.1111/j.14710307.2009.00535.x.

El-Agamy, E. I., Nawar, M., Shamsia, S. M., Awad, S., \& Haenlein, G. F. (2009). Are camel milk proteins convenient to the nutrition of cow milk allergic children? Small Ruminant Research, 82(1), 1-6. http:// dx.doi.org/10.1016/j.smallrumres.2008.12.016.

Farnsworth, J., Li, J., Hendricks, G., \& Guo, M. (2006). Effects of transglutaminase treatment on functional properties and probiotic culture survivability of goat milk yogurt. Small Ruminant Research, 65(1-2), 113-121. http://dx.doi.org/10.1016/j.smallrumres.2005.05.036.

Farrell, H., Qi, P., \& Uversky, V. (2006). New views of protein structure: applications to the caseins: protein structure and functionality. In M. L. Fishman, P. X. Qi \& L. Wicker (Eds.), Advances in biopolymers: molecules, clusters, networks, and interactions (pp. 52-70). Washington: American Chemical Society.

Food and Agriculture Organization - FAO. (2017). FAOSTAT. Rome: FAO. Retrieved from http://www.fao.org/faostat/en/\#

Fuongfuchat, A., Seetapan, N., Makmoon, T., Pongjaruwat, W., Methacanon, P., \& Gamonpilas, C. (2012). Linear and non-linear viscoelastic behaviors of crosslinked tapioca starch/polysaccharide systems. Journal of Food Engineering, 109(3), 571-578. http://dx.doi. org/10.1016/j.jfoodeng.2011.10.022.

Getachew, F. (2003). A review of the small scale dairy sector in Ethiopia: FAO prevention of food losses programme. milk and milk products, post-harvest losses and food safety in sub-saharan Africa and Near East. Rome: FAO.

Glantz, M., Devold, T. G., Vegarud, G. E., Lindmark Månsson, H., Stålhammar, H., \& Paulsson, M. (2010). Importance of casein micelle size and milk composition for milk gelation. Journal of Dairy Science, 93(4), 1444-1451. http://dx.doi.org/10.3168/jds.2009-2856. PMid:20338421.

González-Reyes, E., Méndez-Montealvo, G., Solorza-Feria, J., ToroVazquez, J., \& Bello-Perez, L. A. (2003). Rheological and thermal characterization of Okenia hypogaea (Schlech. \& Cham.) starch. Carbohydrate Polymers, 52(3), 297-310. http://dx.doi.org/10.1016/ S0144-8617(02)00291-6.

Holt, C. (1998). Casein micelle substructure and calcium phosphate interactions studied by sephacryl column chromatography. Journal of Dairy Science, 81(11), 2994-3003. http://dx.doi.org/10.3168/jds. S0022-0302(98)75863-1.
Hsu, S., Lu, S., \& Huang, C. (2000). Viscoelastic changes of rice starch suspensions during gelatinization. Journal of Food Science, 65(2), 215-220. http://dx.doi.org/10.1111/j.1365-2621.2000.tb15982.x.

Kamal, M., Foukani, M., \& Karoui, R. (2017). Rheological and physical properties of camel and cow milk gels enriched with phosphate and calcium during acid-induced gelation. Journal of Food Science and Technology, 54(2), 439-446. http://dx.doi.org/10.1007/s13197-0162480-9. PMid:28242943.

Kappeler, S. (1998). Compositional and structural analysis of camel milk proteins with emphasis on protective proteins. Zurich: ETH.

Kasapis, S., Sablani, S. S., \& Biliaderis, C. G. (2000). Dynamic oscillation measurements of starch networks at temperatures above $100{ }^{\circ} \mathrm{C}$. Carbohydrate Research, 329(1), 179-187. http://dx.doi.org/10.1016/ S0008-6215(00)00161-0. PMid:11086697.

Kaskous, S. (2016). Importance of camel milk for human health. Emirates Journal of Food and Agriculture, 28(3), 158-163. http:// dx.doi.org/10.9755/ejfa.2015-05-296.

Khan, A. A., \& Alzohairy, M. (2011). Hepatoprotective effects of camel milk against CCl4-induced hepatotoxicity in Rats. Asian J Biochem, 6(2), 171-180. http://dx.doi.org/10.3923/ajb.2011.171.180.

Konuspayeva, G., Camier, B., Gaucheron, F., \& Faye, B. (2014). Some parameters to process camel milk into cheese. Emirates Journal of Food and Agriculture, 26(4), 354-358. http://dx.doi.org/10.9755/ ejfa.v26i4.17277.

Lagarrigue, S., \& Alvarez, G. (2001). The rheology of starch dispersions at high temperatures and high shear rates: a review. Journal of Food Engineering, 50(4), 189-202. http://dx.doi.org/10.1016/S02608774(00)00239-9.

Mal, G., Sena, D. S., Jain, V., \& Sahani, M. (2006). Therapeutic value of camel milk as a nutritional supplement for multiple drug resistant (MDR) tuberculosis patients. Israel Journal of Veterinary Medicine, 61(3-4), 88.

Mohamed, A. A., Hussain, S., Alamri, M. S., Abdo Qasem, A. A., Ibraheem, M. A., \& Alhazmi, M. I. (2019). Dynamic rheological properties of corn starch-date syrup gels. Journal of Food Science and Technology, 56(2), 927-936. http://dx.doi.org/10.1007/s13197018-03558-9. PMid:30906050.

Morin, D., Rowan, L., \& Hurley, W. (1995). Comparative study of proteins, peroxidase activity and $\mathrm{N}$-acetyl- $\beta$-D-glucosaminidase activity in llama milk. Small Ruminant Research, 17(3), 255-261. http://dx.doi.org/10.1016/0921-4488(95)00679-F.

Ozer, B., Avni Kirmaci, H., Oztekin, S., Hayaloglu, A., \& Atamer, M. (2007). Incorporation of microbial transglutaminase into non-fat yogurt production. International Dairy Journal, 17(3), 199-207. http://dx.doi.org/10.1016/j.idairyj.2006.02.007.

Rahman, I. E. A., Dirar, H. A., \& Osman, M. A. (2009). Microbiological and biochemical changes and sensory evaluation of camel milk fermented by selected bacterial starter cultures. African Journal of Food Science, 3(12), 398-405.

Rao, M., Gupta, R., \& Dastur, N. (1970). Camels' milk and milk products. Indian Journal of Dairy Science, 23(2), 71-78.

Rodrigues, J. F., Siman, I. B., Oliveira, L. E. A., Barcelos, A. F., Oliveira, R. A. A., Silva, R., \& Cruz, A. G. (2021). Use of diaries as a research strategy on sensory perception andconsumer behavior of Canastr a cheese. Journal of Sensory Studies, 36(2), e12627. http://dx.doi. org/10.1111/joss.12627.

Salih, M. M., \& Ahmed Hamid, O. I. (2013). Effect of fortifying camel's milk with skim milk powder on the physicochemical, microbiological and sensory characteristics of set yoghurt. Advance Journal of Food 
Science and Technology, 5(6), 765-770. http://dx.doi.org/10.19026/ ajfst.5.3161.

Shabo, Y., Barzel, R., Margoulis, M., \& Yagil, R. (2005). Camel milk for food allergies in children. IMAJ-RAMAT GAN, 7(12), 796-798. PMid:16382703.

Shalash, M. (1980). Utilization of camel meat and milk in human nourishment. Provisional Report, International. Foundations of Science, (6), 285-306.

Shamsia, S. (2009). Nutritional and therapeutic properties of camel and human milks. International Journal of Genetics and Molecular Biology, 1(4), 52-58.

Singh, R., Ghorui, S., \& Sahani, M. (2006). Camel milk: properties and processing potential. In M. S. Sahani (Ed.), The Indian camel (pp. 59-73). Bikaner: NRCC.

Tattiyakul, J., \& Rao, M. (2000). Rheological behavior of crosslinked waxy maize starch dispersions during and after heating.
Carbohydrate Polymers, 43(3), 215-222. http://dx.doi.org/10.1016/ S0144-8617(00)00160-0.

Torres, F. R., Silva, H. L. A., Cutrim, C. S., \& Cortez, M. A. S. (2020). Consumer perception of Petit-Suisse cheese: identifying market opportunities for the Brazilian dairy industry. Food Science and Technology (Campinas), 40(Suppl. 2), 653-660. http://dx.doi. org/10.1590/fst.38319.

Xu, J., Mohamed, A. A., Hojilla-Evangelista, M. P., \& Sessa, D. J. (2006). Viscoelastic properties of lupin proteins produced by ultrafiltrationdiafiltration. Journal of the American Oil Chemists' Society, 83(6), 553-558. http://dx.doi.org/10.1007/s11746-006-1239-2.

Yagil, R. (1982). Camels and camel milk. Rome: FAO.

Zouari, A., Mtibaa, I., Triki, M., Jridi, M., Zidi, D., Attia, H., \& Ayadi, M. A. (2020). Effect of spray-drying parameters on the solubility and the bulk density of camel milk powder: a response surface methodology approach. International Journal of Dairy Technology, 73(3), 616-624. http://dx.doi.org/10.1111/1471-0307.12690. 